(c) American Dairy Science Association, 2004.

\title{
Induced Lactation in Nonpregnant Cows: Profitability and Response to Bovine Somatotropin
}

\author{
A. L. Magliaro, ${ }^{1}$ R. S. Kensinger, ${ }^{1}$ S. A. Ford, ${ }^{2}$ M. L. O'Connor, ${ }^{1}$ \\ L. D. Muller, ${ }^{1}$ and R. Graboski ${ }^{1}$ \\ 'Department of Dairy and Animal Science and \\ ${ }^{2}$ Department of Agricultural Economics and Rural Sociology, \\ The Pennsylvania State University, University Park 16802
}

\section{ABSTRACT}

Significant culling of high-producing cows with low fertility reduces profitability of dairy farms as those cows are replaced with heifers. Induced lactation of nonpregnant cows may be a management alternative to reduce culling and increase profits. The objectives of this study were to evaluate the efficacy of bovine somatotropin (bST) to increase milk production in cows induced into lactation with estrogen plus progesterone, and to determine the profitability of inducing cows into lactation vs. using replacement heifers entering the herd as first-lactation cows. Parity 1 or greater, nonpregnant, healthy Holstein cows $(n=28)$ were induced into lactation by administration of estradiol- $17 \beta(0.075$ $\mathrm{mg} / \mathrm{kg}$ of body weight [BW] per d) and progesterone $(0.25 \mathrm{mg} / \mathrm{kg}$ of BW per d) for $7 \mathrm{~d}$. Milking began on d 18. Cows were randomly assigned to control or bST treatment groups on $\mathrm{d} 37 \pm 20$ of milking, and milk production was compared for $70 \mathrm{~d}$. After the 70-d comparison, all cows received bST for the duration of lactation. Cows receiving bST produced more milk $(28.4 \mathrm{~kg} /$ d) than controls $(24.1 \mathrm{~kg} / \mathrm{d})$, with variable yields among cows. For the economic analysis, induced cows were compared to first-lactation cows in the same herd using fair market value for costs and multiple component pricing for milk. Net present value for an induced cow (\$1966) was significantly greater than that for a firstlactation cow (\$1446). Our data suggest that bST use in induced cows is profitable. If a reliable method were developed and approved by the FDA, inducing nonpregnant cows into lactation could be used by dairy producers to increase profitability.

(Key words: induced lactation, somatotropin, economics, dairy cattle)

Abbreviation key: rbPRL = recombinant bovine prolactin; NPV = net present value.

Received February 27, 2004.

Accepted June 9, 2004

Corresponding author: R. S. Kensinger; e-mail: rsk7@psu.edu

\section{INTRODUCTION}

Significant culling of high-producing cows with low fertility reduces profitability of dairy farms as those cows are replaced with heifers. Induced lactation of nonpregnant cows may be a management alternative to increase profits. Adding replacement heifers to the milking string is one of the largest costs of dairy farming. It requires 25 to 26 mo and rearing costs of $\$ 1150$ to $\$ 1350$ to bring a single heifer into production (Heinrichs, 1996). There is potential to increase income by reducing the number of heifers raised or by selling excess heifers. An improved method to induce nonpregnant cows into lactation could return to production valuable healthy cows that would otherwise be culled and at the same time decrease the need for replacement heifers.

Smith and Schanbacher (1973) showed that lactation could be induced using a 7-d treatment period of estradiol-17 $\beta$ and progesterone. Their treatment was designed to mimic the high levels of these steroids observed during the last month of pregnancy in cattle, when significant mammary development occurs. Milk production was variable, ranging from 63 to $106 \%$ of the best previous lactation. Subsequent studies also have shown large variations in milk yields from cows hormonally induced into lactation (Collier et al., 1975, 1977; Chakriyarat et al., 1978; Kensinger et al., 1979; Byatt et al., 1994). It is not clear why some animals respond to the induced lactation process better than others. However, a role for prolactin in induced lactation is evident because induced cows treated with reserpine to increase prolactin concentrations produced more milk than controls (Collier et al., 1977; Kensinger et al., 1979). Byatt et al. (1997) reported that total mammary DNA was not different between induced heifers treated with recombinant bovine prolactin (rbPRL) on treatment $\mathrm{d} 8$ to 14 compared to their induced controls. However, the rbPRL treatment did increase dry tissue weight and stimulated mammary differentiation.

Several studies have shown milk production in induced animals to be 60 to $70 \%$ of previous lactation 
yield (Smith and Schanbacher, 1973; Collier et al., 1975, 1977; Chakriyarat et al., 1978; Kensinger et al., 1979). Fowler et al. (1991) proposed that lower than normal milk production in induced animals was the result of incomplete proliferation of mammary tissue rather than inadequate differentiation of secretory cells. In their study with goats, maximum parenchymal volume as measured by magnetic resonance imaging was not attained until wk 8 of lactation and then was only $70 \%$ of the normal parenchymal volume. Milk production per unit of parenchyma was similar to that observed in postpartum lactations (Fowler et al., 1991).

Jordan et al. (1981) observed that concentrations of estrogen and progesterone in the milk produced by cows hormonally induced into lactation were similar to those in the milk of postpartum cows. They also reported that induced cows had lower plasma bST concentrations than postpartum cows. In theory, bST should enhance metabolism in induced cows as it does in postpartum cows (Bauman, 1992) to support greater levels of milk production than previously observed. Byatt et al. (1997) observed an increase in milk production when induced heifers were treated with bST over a $10-d$ period, but a control group was not available for that comparison. The present study is the first controlled study to compare milk production responses to bST in cows hormonally induced into lactation.

In order for induced lactation to be adopted as a management tool on dairy farms, it must be economically viable. Under traditional management schemes, cows that fail to conceive are culled and replaced with heifers. Allaire et al. (1977) reported that reproductive problems account for $47 \%$ of the cows culled from the dairy herd between the ages of 3 and $8 \mathrm{yr}$. A more recent report estimated this figure to be $26.7 \%$ (NAHMS, 1996). This is troubling because it is often the higher milk producers that are at the greatest risk of failing to conceive in a timely manner, as discussed by Loeffler et al. (1999). Culling such cows represents a loss of some of the most profitable cows in the herd. Therefore, a second objective of the present study was to compare the profitability of induced cows to first-lactation cows in the same herd. To our knowledge, no reports in the literature have used a dairy systems approach to quantify the economic value of using induced lactation technology.

\section{MATERIALS AND METHODS}

Parity 1 or greater, nonpregnant, healthy Holstein cows $(\mathrm{n}=28)$ were induced into lactation following a dry period $\geq 50 \mathrm{~d}$. Cows had a mean BW of $683 \pm 68 \mathrm{~kg}$ and from 1 to 5 previous lactations. The cows were induced in 6 different groups, with 4 or 6 cows per group. Cows received daily subcutaneous injections of estradiol-17 $\beta$ (0.075 mg/kg BW; E-8875, Sigma-Aldrich, St. Louis, MO) and progesterone $(0.25 \mathrm{mg} / \mathrm{kg} \mathrm{BW}$; P0130, Sigma-Aldrich) for $d 1$ to 7 of the experiment. Hormone solutions were prepared in absolute ethanol to achieve $15 \mathrm{mg} / \mathrm{mL}$ estradiol- $17 \beta$ and $50 \mathrm{mg} / \mathrm{mL}$ progesterone. During the induction phase of the study, cows were housed in a climate-controlled barn in individual tie stalls to prevent injury due to estrous-like behavior associated with the estrogen/progesterone treatment.

Milking began on d 18 of the experiment, and cows were milked once per day until production reached approximately $4 \mathrm{~kg}$. Thereafter, milking was twice daily until cows returned to the university herd at, on average, $26 \mathrm{~d}$ of lactation. They were then milked 2 or 3 times daily according to current herd management practice at the time. Cows in the first 3 groups were milked twice daily throughout lactation. After the third group, herd management protocol changed so that all cows were milked 3 times daily until mid-lactation and twice daily thereafter. Cows within each group were paired based on milk production during the first 20 $\mathrm{d}$ of induced lactation. Within each pair, cows were randomly assigned to either bST or control treatment. In all other respects, pairs were managed identically during this portion of the experiment. Each pair commenced bST or control treatment on $\mathrm{d} 37 \pm 20 \mathrm{~d}$ of lactation. The reason for variation in start of the bST treatment period was that induced cows increased in milk production at different rates, and we did not return cows to the main herd until production exceeded $12 \mathrm{~kg} /$ $\mathrm{d}$; then, the bST/control comparison did not begin until the next herd bST treatment day, which could be 1 to $13 \mathrm{~d}$ after their return to the herd. Bovine somatotropin (Posilac, Monsanto Co., St. Louis, MO) was administered at 2 -wk intervals for $10 \mathrm{wk}$. During this time, there were 2 DHIA test days to determine milk composition. After this 70-d bST/control treatment comparison, all induced cows received bST biweekly. Daily milk yield and monthly milk composition were collected for the entire lactation.

Before initiation of lactation, cows were fed a TMR designed to meet the NRC requirements of late gestation dairy cows (NRC, 1989). Beginning $2 \mathrm{~d}$ before milking commenced (treatment d 16), cows received a mixture containing equal parts of the dry cow TMR and a lactating cow TMR. Once milking began, cows received the lactating cow TMR ad libitum. Cows continued to receive the same lactating cow TMR in freestall housing upon their return to the university dairy herd. Ration compositions presented (Table 1) are representative of those fed over the course of this research. Because the experiment was conducted over several years, slight 
Table 1. Diet composition and analyses for representative diets used.

\begin{tabular}{llc}
\hline $\begin{array}{l}\text { Ingredient, } \\
\text { \% DM }\end{array}$ & $\begin{array}{l}\text { Dry } \\
\text { cow }\end{array}$ & $\begin{array}{l}\text { Lactating } \\
\text { cow } \\
\text { TMR }\end{array}$ \\
\hline Corn silage & 34.9 & 28.6 \\
Alfalfa hay, chopped & - & 8.9 \\
Grass hay, chopped & 19.9 & - \\
Grass hay silage & 19.7 & 4.2 \\
Alfalfa hay silage & - & 8.4 \\
Ground corn & 5.9 & 16.5 \\
Soybeans, cooked & - & 5.0 \\
Distillers corn & - & 7.5 \\
Canola meal & 8.4 & 10.1 \\
Wheat middlings & - & 3.7 \\
Barley & - & 3.7 \\
Dry cow grain mix & 10.5 & - \\
Dicalcium phosphate & - & 0.08 \\
Limestone & 0.15 & 1.16 \\
Vitamin/mineral mix & - & 2.2 \\
Composition & & \\
DM, \% & 43.1 & 52.8 \\
CP, \% & 14.5 & 17.7 \\
ADF, \% & 27.5 & 18.8 \\
NDF, \% & 44.2 & 33.4 \\
CaDF, \% & 0.58 & 0.90 \\
P, \% & 1.39 & 0.48 \\
NE, lactation, Mcal/kg DM & 1.55 & 1.68 \\
\hline
\end{tabular}

ration changes were inevitable. However, the nutrient content of the TMR remained constant. This experiment was approved by the Institutional Animal Care and Use Committee at The Pennsylvania State University.

Data were analyzed using the GLM procedure of SAS (SAS Inst., Inc., Cary, NC). For the bST/control treatment comparison, the model included Treatment, Group, Cow (treatment $\times$ group), and Day of Treatment. Main effects were tested against Cow (treatment $x$ group) as an error term. A similar analysis was performed for full lactation data comparing all induced cows with peer first-lactation cows from the same herd.

For the profitability analysis, 27 study cows were compared to peer first-lactation cows in the same herd. One induced cow that completed the bST phase of the study was not used in the profitability analysis because it was culled for cosmetic appearance (i.e., not for productive or functional reasons) before 150 DIM. A peer cohort of first-lactation cows was selected for each of the 27 remaining induced cows based upon similar first day of milking to balance for environmental effects. The induced cows and peer first-lactation cows were housed together and were fed the same ration. All peer firstlactation cows received bST beginning on the first herd treatment day $\geq 60 \mathrm{~d}$ in milk according to routine herd management protocol. Monthly milk yield and composition and reproduction data were collected for the induced cows and the peer first-lactation cows for their entire lactations. Induced cows and peer first-lactation cows were subject to routine herd management protocols regarding milking, breeding, and health care.

The economic analysis included a determination of monthly income over costs for each animal and then a calculation of the present value of the 12-mo stream of those net incomes. Present value analysis was used, rather than a simple accounting of realized income, to account for differences in the timing of cull income and replacement values because animals left the experiment during different months.

The present values for each animal, $\mathrm{j}$, were calculated using the following equation:

$$
\begin{gathered}
P V_{j}=\sum_{i} d_{i} * \\
\left(M_{i j}+F_{i j}+P_{i j}-C_{i j}-H_{i j}-A_{i j}+R_{i j}-S_{i j}\right)
\end{gathered}
$$

where,

$\mathrm{PV}_{\mathrm{j}}=$ the present value of monthly net returns to animal j;

$\mathrm{d}_{\mathrm{i}}=$ the discount factor in month $\mathrm{i}$;

$\mathrm{M}_{\mathrm{ij}}=$ the base value of milk sold in month $\mathrm{i}$ from animal j;

$\mathrm{F}_{\mathrm{ij}}=$ the fat premium of the milk sold in month $\mathrm{i}$ from animal $\mathrm{j}$;

$\mathrm{P}_{\mathrm{ij}}=$ the protein premium of the milk sold in month i from animal $\mathrm{j}$;

$\mathrm{C}_{\mathrm{ij}}=$ the feed cost for animal $\mathrm{j}$ in month $\mathrm{i}$;

$\mathrm{H}_{\mathrm{ij}}=$ the cost of bST and induced lactation treatment for animal $\mathrm{j}$ in month $\mathrm{i}$;

$A_{i j}=$ the cost of artificial insemination services for animal $\mathrm{j}$ in month $\mathrm{i}$;

$R_{i j}=$ the value of animal $j$ (or its replacement) at the termination of its participation in the trial in month I in month i;

$\mathrm{S}_{\mathrm{ij}}=$ the net replacement cost of animal $\mathrm{j}$, if culled in month $i$.

The variables used in the present value equation are fairly straightforward except, perhaps, the roles of $R_{i j}$ and $S_{i j}$. All animals, $j$, were credited with their animal value, $R_{\mathrm{ij}}$, at the end of their participation in the study. If an animal was culled from the study, however, it was still credited with its value at the time it was culled but was also charged a net replacement cost, $\mathrm{S}_{\mathrm{ij}}$.

Values used in the economic analysis are presented in Table 2. These values were chosen based on current market rates at the time of the study or were calculated based on cost of materials and labor. The resultant present values were then compared in statistical analyses using SPSS (SPSS, Inc., Chicago, IL). A sensitivity analysis was also conducted to determine the present value outcomes if milk prices and heifer replacement costs varied by $20 \%$ above or below these market values. 
Table 2. Economic parameters used in the present value analysis.

\begin{tabular}{ll}
\hline Component & Economic parameter \\
\hline Milk price & $\$ 0.297 / \mathrm{kg}$ \\
Fat premium/discount (per 0.1\% over/under 3.5\%) & $\$ 0.0033 / \mathrm{kg}$ \\
Protein premium/discount (per 0.1\% over/under 3.2\%) & $\$ 0.0055 / \mathrm{kg}$ \\
Milk hauling & $\$ 0.013 / \mathrm{kg}$ \\
Induction treatment cost (materials only) & $\$ 10.58 / \mathrm{cow}$ \\
bST treatment cost & $\$ 6.07 / \mathrm{injection}$ \\
Daily feed cost & $\$ 3.93 /$ animal \\
Value of cull animal & $\$ 500$ \\
Value of milking animal & $\$ 1200$ \\
Discount factor & $6 \%$ \\
\hline
\end{tabular}

A second economic analysis was done to estimate the profitability of bST use in induced cows. Because the $\mathrm{bST} /$ control treatment period was only $70 \mathrm{~d}$ after which all cows received bST, an estimate of monthly milk production of induced cows over a year without bST use was generated. The average milk production of all bSTtreated cows was calculated. This figure was then reduced by the percentage increase due to bST that was observed during the 70-d treatment period. Milk hauling charges and feed consumption were also reduced, and cost of bST was removed. The bST-treated animal was then compared to the estimated value for an induced cow receiving no bST during its lactation.

\section{RESULTS}

\section{Response to bST}

Induced cows that received bST produced $17.8 \%$ more milk than controls over the 70-d treatment period. There was a significant treatment $\times$ time interaction $(P<0.01)$ that reflected the fact that the difference in

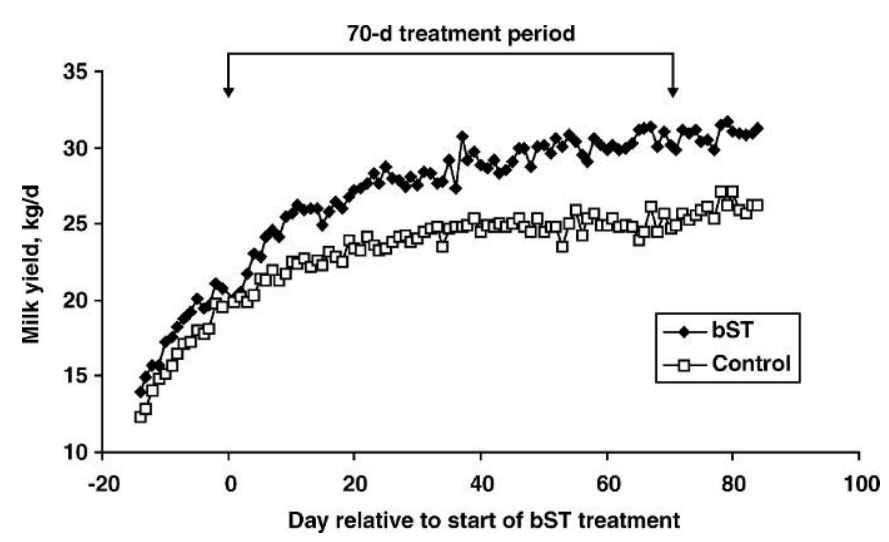

Figure 1. Comparison of milk yields of cows induced into lactation and treated with bST with induced cows not treated with bST (control). Cows treated with bST are represented by the solid diamond $(\checkmark)$ and controls by the open square $(\square)$. The 70-d bST treatment period began on $\mathrm{d} 37 \pm 20$ of lactation. Significant Treatment $\times$ Time interaction, $\mathrm{SE}=0.69, P<0.01$. milk production of bST-treated and control cows was greater after several 14-d cycles of treatment (Figure 1). Induced cows attained peak milk production of 32.2 $\pm 11.5 \mathrm{~kg} / \mathrm{d}$ at $125 \pm 47 \mathrm{~d}$ of lactation. Whereas induced cows required more days to attain peak lactation than postpartum cows, duration of lactation was normal, as induced cows averaged $289 \pm 74$ DIM.

Milk composition and somatic cell counts were similar between bST-treated and control cows during induced lactations, averaging $3.80 \%$ fat and $3.34 \%$ protein (Table 3). These values are in the normal range for Holstein cows. Once lactation was established, the induced cows were similar to herdmates with respect to productivity, health, and behavior.

\section{Induced Cows vs. Peer First-Lactation Cows}

Milk production was not different between induced cows and peer first-lactation cows that had a gestation and parturition (Table 4). However, induced cows produced milk with a higher fat and protein content $(P<$ 0.05). The number of days in milk was not different between groups. The induced cows, however, averaged fewer DIM than peer first-lactation cows, in part, due to earlier conception in the induced cows. The general health of all induced cows was excellent, with no mobility problems observed. This is consistent with other studies where animals were restrained for the first 30

Table 3. Effect of bST on yield and composition of milk from cows induced into lactation. ${ }^{1}$

\begin{tabular}{lcccc}
\hline Component & bST & Control & SE & $P<$ \\
\hline Milk yield, kg/d & 28.4 & 24.1 & 0.69 & 0.01 \\
Fat, \% & 3.78 & 3.82 & 0.13 & NS \\
Protein, \% & 3.28 & 3.40 & 0.06 & NS \\
SCC, $\times 1000$ & 275 & 408 & 158 & NS \\
\hline
\end{tabular}

${ }^{1}$ The bST vs. control treatments were compared over a 70 -d period beginning on d $37 \pm 20$ of lactation, with 14 cows per group. Milk production was measured daily and a significant Treatment $\times$ Time interaction was observed. For analysis of milk composition, 2 milk samples collected at 30-d intervals were used. 
Table 4. Milk yield (12 mo) and composition and DIM for cows induced into lactation $(\mathrm{n}=27)$ and peer first-lactation cows $(\mathrm{n}=27)^{1}$

\begin{tabular}{lllll}
\hline & $\begin{array}{l}\text { Induced } \\
\text { cows }\end{array}$ & $\begin{array}{l}\text { Peer } \\
\text { first-lactation } \\
\text { cows }\end{array}$ & SE & $P<$ \\
\hline Milk yield, kg & 7405 & 8431 & 565.7 & NS \\
Fat, \% & 3.85 & 3.41 & 0.14 & 0.05 \\
Fat yield, kg & 277.5 & 294.0 & 21.3 & NS \\
Protein, \% & 3.48 & 3.24 & 0.05 & 0.01 \\
Protein yield, kg & 253.2 & 272.9 & 18.9 & NS \\
DIM & 286 & 305 & 14 & NS \\
\hline
\end{tabular}

${ }^{1} \mathrm{~A}$ peer first-lactation cow was selected as a cohort for each induced cow based upon first day of milking to balance for environmental effects. Samples for milk composition were collected monthly for a 12-mo period.

d following initiation of treatment (Collier et al., 1975; Kensinger et al., 1979).

Reproductive performance and outcomes of induced cows and peer first-lactation cows were compared (Table 5). Six induced cows and 7 peer first-lactation cows were culled during their lactations. Services per cow for all animals in each group was 1.6 for induced cows and 2.0 for peer first-lactation cows. For pregnant animals, there was a trend for reduced number of services per pregnancy in the induced cows (1.6) compared to the peer first-lactation cows (2.1). The interval between lactations averaged 12.5 mo for induced cows and 13.4 mo for first-lactation cows. Twenty-one of the induced cows and 20 of the peer first-lactation cows subsequently calved.

\section{Economic Analysis}

Mean net present value (NPV) for induced cows (\$1966) was significantly higher than that for peer first- lactation cows ( $\$ 1446$; Table 6). This is an annual NPV advantage of $\$ 520$ per cow induced into lactation. If actual milk price had been $20 \%$ higher, the NPV advantage for induced cows would decrease to $\$ 489$. With a milk price $20 \%$ lower, the NPV advantage increased to $\$ 553$. As expected, NPV advantage for the induced cows increased with higher replacement cost (\$639) and decreased with lower replacement cost ( $\$ 400$; Table 6$)$. In all cases, NPV was greater for the induced cows than for the peer first-lactation cows.

A projected comparison of bST profitability in induced cows estimated that the annual NPV advantage for treating induced cows with bST would average \$261/ cow.

\section{DISCUSSION}

Bovine somatotropin augmented milk yields in cows hormonally induced into lactation much like that observed in postpartum animals (Bauman et al., 1999).

Table 5. Reproductive performance and outcomes of cows induced into lactation and peer first-lactation cows $\left(n=27\right.$ in each). ${ }^{1}$

\begin{tabular}{lcccc}
\hline & $\begin{array}{l}\text { Induced } \\
\text { cows }\end{array}$ & $\begin{array}{l}\text { Peer } \\
\text { first-lactation } \\
\text { cows }\end{array}$ & SE & $P<$ \\
\hline Culled during lactation & 6 & 7 & & \\
$\quad$ Low milk yield & 3 & 1 & & \\
Reproductive failure & 3 & 1 & & \\
Injury, health problem & & 3 & & \\
Poor temperament & 21 & 1 & 0.21 & NS \\
Poor udder type & 1.6 & 20 & 0.19 & NS \\
Calved subsequently & 1.6 & 2.0 & 0.30 & 0.05 \\
Services/cow, all cows & 12.5 & 13.4 & & \\
Services/pregnancy, pregnant cows & & 1 & & \\
Interval between lactations, ${ }^{2}$ mo & & & & \\
\hline
\end{tabular}

\footnotetext{
${ }^{1} \mathrm{~A}$ peer first-lactation cow was selected as a cohort for each induced cow based upon first day of milking to balance for environmental effects.

${ }^{2}$ Interval between lactations is defined as the number of months between the first day of milking in the present and subsequent lactations.
} 
Table 6. Net present value, in dollars, of a 12-mo stream of net incomes for cows induced into lactation and peer first-lactation cows $\left(\mathrm{n}=27\right.$ in each). ${ }^{1}$

\begin{tabular}{lllll}
\hline $\begin{array}{l}\text { Net present } \\
\text { value }\end{array}$ & $\begin{array}{l}\text { Induced } \\
\text { cows }\end{array}$ & $\begin{array}{l}\text { Peer } \\
\text { first-lactation } \\
\text { cows }\end{array}$ & SE & $P<$ \\
\hline Actual & 1966 & 1446 & 145 & 0.05 \\
Milk prices 20\% higher & 2422 & 1933 & 177 & 0.07 \\
Milk prices 20\% lower & 1509 & 956 & 113 & 0.01 \\
Replacement cost 20\% higher & 2058 & 1419 & 152 & 0.01 \\
Replacement cost 20\% lower & 1873 & 1473 & 138 & 0.06 \\
\hline
\end{tabular}

${ }^{1}$ Data used in net present value analysis included milk price $(\$ 0.297 / \mathrm{kg})$, fat premium or discount per $0.1 \%$ over or under $3.5 \%(\$ 0.0033 / \mathrm{kg})$, protein premium or discount per $0.1 \%$ over or under $3.2 \%(\$ 0.0055 /$ $\mathrm{kg})$, milk hauling charge $(\$ 0.013 / \mathrm{kg})$, induction treatment $(\$ 10.58 / \mathrm{cow}$, materials only), bST treatment $(\$ 6.07 /$ injection), daily feed (\$3.93/animal), and values of calf $(\$ 100)$, cull animal ( $\$ 500)$, and milking animal $(\$ 1200)$. A discount factor of $6 \%$ was used. These values were chosen based upon current market rates in Pennsylvania at the time of the study or were calculated based on cost of materials and labor.

The response to bST increased over the 70-d treatment period. This agrees with industry data showing that maximum response to bST occurs after several injection periods (Bauman et al., 1999). Analysis of the milk data from the fifth bST injection cycle showed that bSTtreated cows produced $21.9 \%$ more milk than the control-induced cows $(P<0.05)$. This is the first demonstration that cows hormonally induced into lactation and then treated with bST produce more milk than induced cows that are not treated with bST.

Milk composition was similar between bST-treated and control animals (Table 3). Postpartum cows in positive energy balance also have similar concentrations of milk fat and protein during bST treatment when compared to control herdmates (Bauman, 1992). The cows in this study increased in milk yield slowly and did not attain peak production until $125 \pm 47 \mathrm{~d}$ of milking. Previous studies on induced lactation have also demonstrated this gradual increase in milk yield and longer time to peak production (Smith and Schanbacher, 1973, 1974; Collier et al., 1975; Erb et al., 1976; Collier et al., 1977; Bel Isle and Swanson, 1978; Kensinger et al., 1979; Jordan et al., 1981; Fowler et al., 1991). It appears that cows induced into lactation make the transition from the dry to lactating state easily, with little difficulty maintaining adequate feed intake.

Milk yields were not significantly different between induced cows and peer first-lactation cows. Generally, milk production is higher for animals in their second and later lactations (Larson, 1985). Even though our induced cows had greater body capacities to support higher production compared with peer first-lactation cows, they may have had similar amounts of mammary secretory tissue. For the induced cows with previous lactation data available $(\mathrm{n}=24)$, mean daily milk production averaged $80 \pm 19 \%$ of the previous lactation (296 \pm 79 DIM). The percent of previous milk production observed in the current study is higher than reports of others who observed induced lactation milk yields averaging 60 to $70 \%$ of previous production (Smith and Schanbacher, 1973; Collier et al., 1975; Collier et al., 1977; Chakriyarat et al., 1978; Kensinger et al., 1979). Administration of bST in the present study contributed to this improved milk production. However, the fact that induced cows did not average $100 \%$ of previous production suggests that we have not mimicked all the physiological changes associated with pregnancy and parturition.

Yields of milk fat and protein by induced cows were nearly identical to the yields of the peer first-lactation cows (Table 4). The induced cows conceived earlier than the peer first-lactation cows, and the demands of a more advanced pregnancy would likely cause a more rapid decrease in milk production. Whereas milk yields were slightly (nonsignificantly) higher for peer first-lactation cows, milk fat and protein percentages were higher for induced cows. Milk fat and protein composition for postpartum cows in their third or greater lactation at the Penn State Dairy Cattle Research and Teaching Center during the 3-yr period of this study averaged 3.47 and $3.11 \%$, respectively. This is lower than the values of 3.85 and $3.48 \%$ for milk fat and protein, respectively, observed in our induced animals. Thus, the lower volume of milk produced by induced cows is somewhat compensated by the economic value of higher solids components.

Three of the 28 induced cows were purchased without any previous records. Sixteen of 25 cows with previous records available had $\geq 3$ services, and yet none were pregnant at the start of our study. Twenty-six of the 28 cows (93\%) in the present study achieved pregnancy (although 3 of the pregnant cows subsequently aborted and 2 were culled for low milk production), and 21 of those cows calved after the induced lactation. The induced cows required 1.6 services per pregnancy (pregnant cows) compared to the 2.1 services per pregnancy 
for the peer first-lactation cows, which contributed to the longer lactation interval for the peer first-lactation cows. The conception rate for the induced cows was quite impressive given their past reproductive history. Others (Smith and Schanbacher, 1973; Collier et al., 1975; Erb et al., 1976; Fulkerson, 1978; Jordan et al., 1981; Lembowicz et al., 1982) have also reported successful breeding in induced cows and heifers that had previously failed to conceive. Collier, Bauman, and Hays (1975) reported that 9 of 16 induced animals resumed normal ovarian activity, and 5 of these 9 conceived. Jordan et al. (1981) observed similar pregnancy rates between induced animals (80\%) and postpartum control animals (83\%). Fulkerson (1978) reported that heifers induced into lactation required 3 services per conception, and $30 \%$ failed to conceive. Conversely, Bel Isle and Swanson (1978) saw no change in fertility status for the 14 problem breeders induced into lactation in their study. The 21 induced cows in the present study that subsequently calved (see Table 5) clearly show another benefit of induced lactation.

The apparent difference in conception rate between the induced cows and peer first-lactation cows in the present study may be associated with calving-related health problems in the first-lactation cows and/or better body condition in the induced cows. As discussed previously, the cows showed a gradual increase in milk production, which allowed time for metabolic adjustments. Few induced cows lost weight, even at peak milk production. Mean weight gain for the induced cows was $17.6 \pm 43 \mathrm{~kg}$ over the first 3 mo of milking.

There were similar cull rates between the induced cows and the peer first-lactation cows, although for somewhat different reasons (Table 5). More induced cows than first-lactation cows were culled for reproductive failure. This is not surprising because cows selected to be induced had failed to conceive during the previous lactation and were older cows. Cull rates for both induced cows and peer first-lactation cows are similar to the national herd cull rate of $24 \%$ reported by NAHMS (1996).

\section{Economics}

Net present value analysis accounts for the value of money over time, so one can equitably compare streams of money over time. The NPV were significantly higher for induced cows compared to peer first-lactation cows. Although induced cows and peer first-lactation cows produced similar volumes of milk, retaining cows already in the herd was more profitable. Animal cost was the largest factor, reducing replacement heifer profitability. The $\$ 1200$ cost used to obtain a heifer, either by purchase or rearing, was a large investment to over- come through subsequent milk sales. As shown by the analysis with $20 \%$ higher and lower replacement costs, NPV advantage of induced lactation increased as heifer replacement cost increased. In addition, as the difference between cull price and cow value (now $\$ 700$ ) increases to $\$ 1000$, the advantage of induced lactation increases to $\$ 819$ per cow per year. When milk prices are lower, induced lactation appeared even more profitable as evidenced by the increased NPV of induced animals relative to peer first-lactation cows. Also, milk from the induced cows was more valuable than that from the peer first-lactation cows because the cows had higher percentages of milk fat and protein.

Significant savings could be realized if dairy farmers were able to retain valuable cows that fail to conceive but are otherwise healthy. If $24 \%$ of animals are culled each year, with $26.7 \%$ of those being for reproductive reasons (NAHMS, 1996), then $6.4 \%$ of the total herd is culled for reproductive reasons. Using this involuntary cull rate of $6.4 \%$, a 500-cow dairy would induce lactation in, rather than cull, 32 cows annually. At an annual NPV advantage of $\$ 520 /$ cow, this translates to an NPV advantage of $\$ 16,640 / \mathrm{yr}$.

Our profitability estimates are conservative, as insemination and health-related costs were not included in our model. With more services required per pregnancy compared to the induced cows, insemination costs would have been higher for the peer first-lactation cows. Additionally, the induced cows suffered none of the costly post-calving disorders such as milk fever, ketosis, retained placenta, and displaced abomasum.

Use of bST in induced cows appears to be profitable, as well. Our estimate of $\$ 261 /$ cow annually is based upon the response to bST during the 70-d period used in this trial. Because maximum production response to bST occurs after numerous injection cycles (Bauman et al., 1999), one might expect the milk yield increases due to bST for the duration of lactation to reflect those seen in the last cycle of our treatment period. During this last 14-d period, bST-treated cows produced 21.9\% more milk than non bST-treated controls. Profitability of bST use would be even higher if this figure had been used to estimate the 12-mo control cow milk production.

The present study is somewhat unique in that it reports data for induced cows for a full lactation and beyond, and is the first to report on the economic value of induced lactation. Farmers can profit, not only from the induced lactation of these cows, but from subsequent lactations, as well. For cows with high genetic merit, induced lactation also provides a mechanism to reduce the loss of valuable genes from the herd, as evidenced by 21 of the induced cows calving subsequent to the induced lactation. 


\section{CONCLUSIONS}

Cows hormonally induced into lactation with estrogen and progesterone produce more milk in response to bST than nonbST-treated controls. Once lactation was established, the induced cows appeared normal in terms of production, health, and behavior. There was significant economic advantage to inducing nonpregnant, healthy cows into lactation rather than using replacement heifers. If this technology is approved by the FDA, it could provide a management alternative for dairy farmers to increase profitability.

\section{ACKNOWLEDGMENTS}

This work was supported by Hatch funds and by USDA special grant no. 96-34281-3028. The authors thank Missy Klepfer, Andy Demma, Eric Penrod, Mark Amsler, and others at the Penn State Dairy Cattle Research and Education Center for their contributions to this project.

\section{REFERENCES}

Allaire, F. R., H. E. Sterwerf, and T. M. Ludwick. 1977. Variations in removal reasons and culling rates with age for dairy females. J. Dairy Sci. 60:254-267.

Bauman, D. E. 1992. Bovine somatotropin. A review. J. Dairy Sci. 75:3432-3451.

Bauman, D. E., R. W. Everett, W. H. Weiland, and R. J. Collier. 1999. Production responses to bovine somatotropin in Northeast dairy herds. J. Dairy Sci. 82:2564-2573.

Bel Isle, D. M., and L. Swanson. 1978. Effect of calf contact on hormonally induced lactation. J. Dairy Sci. 61:509-512.

Byatt, J. C., P. J. Eppard, J. J. Veenhuizen, T. L. Curran, D. F. Curran, M. F. McGrath, and R. J. Collier. 1994. Stimulation of mammogenesis and lactogenesis by recombinant bovine placental lactogen in steroid-primed dairy heifers. J. Endocrinol. 140:33-43.

Byatt, J. C., R. H. Sorbet, P. J. Eppard, T. L. Curran, D. F. Curran, and R. J. Collier. 1997. The effect of recombinant bovine placental lactogen on induced lactation in dairy heifers. J. Dairy Sci. 80:496-503.

Chakriyarat, S., H. H. Head, W. W. Thatcher, F. C. Neal, and C. J. Wilcox. 1978. Induction of lactation: Lactational, physiological, and hormonal responses in the bovine. J. Dairy Sci. 61:1715-1724.

Collier, R. J., D. E. Bauman, and R. L. Hays. 1975. Milk production and reproductive performance of cows hormonally induced into lactation. J. Dairy Sci. 58:1524-1527.

Collier, R. J., D. E. Bauman, and R. L. Hays. 1977. Effect of reserpine on milk production and serum prolactin of cows hormonally induced into lactation. J. Dairy Sci. 60:896-901.

Erb, R. E., E. L. Monk, T. A. Mollett, P. V. Malven, and C. J. Callahan. 1976. Estrogen, progesterone, prolactin and other changes associated with bovine lactation induced with estradiol-17 $\beta$ and progesterone. J. Anim. Sci. 42:644-654.

Fowler, P. A., C. H. Knight, and M. A. Foster. 1991. In-vivo magnetic resonance imaging studies of mammogenesis in non-pregnant goats treated with exogenous steroids. J. Dairy Res. 58:151-157.

Fulkerson, W. J. 1978. Artificial induction of lactation: A comparative study in heifers. Aust. J. Biol. Sci. 31:65-71.

Heinrichs, J. 1996. The importance of heifer raising to a profitable dairy farm. Pages 1-6 Proc. Calf, Heifer, and Dairy Profitability National Conference. NRAES-74.

Jordan, D. L., R. E. Erb, P. V. Malven, C. J. Callahan, and E. L. Veenhuizen. 1981. Artificial induction of lactation in cattle: Effect of modified treatments on milk yield, fertility, and hormones in blood plasma and milk. Theriogenology 16:315-329.

Kensinger, R. S., D. E. Bauman, and R. J. Collier. 1979. Season and treatment effects on serum prolactin and milk yield during induced lactation. J. Dairy Sci. 62:1880-1888.

Larson, B. L., ed. 1985. Lactation. The Iowa State University Press, Ames, IA.

Lembowicz, K., A. Rabek, and L. Skrzeczkowski. 1982. Hormonal induction of lactation in the cow. Br. Vet. J. 138:203-208.

Loeffler, S. H., M. J. deVries, and Y. H. Schukken. 1999. The effects of time of disease occurrence, milk yield, and body condition on fertility of dairy cows. J. Dairy Sci. 82:2589-2604.

NAHMS. 1996. Pages 18-21 in Part I: Reference of 1996 Dairy Management Practices. USDA, Washington, DC.

NRC. 1989. Nutrient Requirements of Dairy Cattle. 6th rev. ed. Natl. Acad. Sci., Washington, DC.

Smith, K. L., and F. L. Schanbacher. 1973. Hormone induced lactation in the bovine. I. Lactational performance following injections of $17 \beta$-estradiol and progesterone. J. Dairy Sci. 56:738-743.

Smith, K. L., and F. L. Schanbacher. 1974. Hormone induced lactation in the bovine. II. Response of nulligravida heifers to modified estrogen-progesterone treatment. J. Dairy Sci. 57:296-303. 